\title{
Process simulation and techno-economic assessment for direct production of advanced bioethanol using a genetically modified Synechocystis sp.
}

\author{
Tiago F. Lopes ${ }^{\mathrm{a}}$, Catarina Cabanas ${ }^{\mathrm{b}}$, André Silva ${ }^{\mathrm{b}, \mathrm{c}}$, Diana Fonseca ${ }^{\mathrm{b}}$, Edgar Santos ${ }^{\mathrm{b}}$, \\ L. Tiago Guerra ${ }^{\mathrm{b}}$, Con Sheahan ${ }^{\mathrm{d}}$, Alberto Reis ${ }^{\mathrm{a}}$, Francisco Gírio ${ }^{\mathrm{a}, *}$ \\ ${ }^{a}$ Laboratório Nacional de Energia e Geologia, I.P., Unidade de Bioenergia, Estrada do Paço do Lumiar 22, 1649-038 Lisbon, Portugal \\ ${ }^{\mathrm{b}}$ A4F-Algafuel SA, Estrada do Paço Lumiar 22, Ed. E, 1649-038 Lisbon, Portugal \\ ${ }^{c}$ LEPABE, Faculty of Engineering, University of Porto, Porto, Portugal \\ ${ }^{\mathrm{d}}$ School of Engineering, University of Limerick, Ireland
}

\section{A R T I C L E I N F O}

\section{Keywords:}

Microalgae

Biorefinery

Bioethanol

Process Modelling

Advanced biofuels

\begin{abstract}
A B S T R A C T
A techno-economic assessment for the direct production of ethanol using a genetically-modified microalgae has been studied. It was considered two main scenarios for process modelling: i) bioenergy-driven microalgae plant, i.e., focused on the production of fuel-grade ethanol and biogas for CHP and, ii) biorefinery-driven microalgae plant, focused on the recovery of added-value bioproducts (zeaxanthin and phycocyanin) along with ethanol and CHP production. These main scenarios and several variants were modelled and optimized for a small-scale demo plant of $1000 \mathrm{~L}_{\mathrm{e}}$ hanol/day and extrapolated for larger production capacities. Results showed that despite the innovative approach of direct production of ethanol by microalgae, the bioenergy-driven scenario is non-feasible under the studied conditions. Conversely, ethanol production becomes economically feasible as co-product in the biorefinery-driven scenario although having payback periods $>10$ years. Furthermore, if only bio-based products are produced the NPV and the payback are even more positive, $104.8 \mathrm{M} €$ and ca. 5 years, respectively.
\end{abstract}

\section{Introduction}

Studies have been proving that fossil fuels reserves are declining while greenhouse gas emissions and consequently global warming are increasing (Abas et al., 2015; Anderson et al., 2016). Carbon dioxide $\left(\mathrm{CO}_{2}\right)$ is a very well-known greenhouse gas that is released from natural sources. Other than this $\mathrm{CO}_{2}$ released from nature, the $\mathrm{CO}_{2}$ produced as a result of industrialization and human activities, mainly by burning fossil fuels (such as transportation, electricity production, industry, agriculture, land use and forestry) has considerably increased its concentration in the atmosphere (IPCC, 2014). Thus, the research for alternative renewable fuels (e.g. biofuels) that can fixate $\mathrm{CO}_{2}$ is of main importance, since it contributes to solving the global warming and energy shortage problems.

In the past few years, microalgae cultivation for biofuel production has gained increasing awareness around the world. It has been demonstrated the potential of converting lipid and carbohydrate from microalgae biomass to biodiesel and bioethanol, respectively (Gouveia et al., 2017; Lopes da Silva et al., 2014) which are interesting alternative fuels to existing fuels from fossil sources (diesel and gasoline) for use in internal combustion engines. Microalgae are fast growing microorganisms, being able to double their biomass in less than one day (Tredici, 2010). This is due to their simple cellular structure, and its large surface to volume ratio gives them the ability to uptake large amount of nutrients from water sources and therefore, promoting their growth rate (Khan et al., 2009). Furthermore, phototrophic microalgae are able to convert solar energy into chemical energy with an efficiency of 10-50 times greater than terrestrial plants, using $\mathrm{CO}_{2}$ as carbon source during photosynthesis (Khan et al., 2009; Li et al., 2008; Rosenberg et al., 2011). Moreover, microalgae cells contain approximately $50 \%$ carbon, in which $1.8 \mathrm{~kg}$ of $\mathrm{CO}_{2}$ are fixed by producing $1 \mathrm{~kg}$ of microalgae biomass (Chisti, 2008). Thus, this method is reported to be technologically feasible and microalgae can consequently have an important role in the bio-fixation of atmospheric $\mathrm{CO}_{2}$ while producing renewable fuels and bioproducts (Lam et al., 2012; Razzak et al., 2017; Zeng et al., 2011; Zhu et al., 2017).

It has been also reported in literature microalgae-based systems for the co-production of biofuels (e.g. bioethanol, biodiesel) and bioproducts under a biorefinery concept. For example, microalgae biorefinery for producing high value products (Chew et al., 2017; Moreno-Garcia et al., 2017), combined algal processing (Dong et al., 2016), integrated $2 \mathrm{G}$ and $3 \mathrm{G}$ biorefineries for biodiesel production (Moncada et al.,

\footnotetext{
* Corresponding author.

E-mail address: francisco.girio@lneg.pt (F. Gírio).
} 